\title{
Commentary: Is the Focus on "Ecosystems" a Liability in the Research on Nature's Services?
}

\author{
Felipe Borrero-Echeverry* and Diego F. Rincon* \\ Corporación Colombiana de Investigación Agropecuaria (AGROSAVIA), Centro de Investigación Tibaitatá, Mosquera, \\ Colombia
}

Keywords: sustainability, ecosystem services (ES), development, system management, nature's contributions to people

\section{A Commentary on}

Is the Focus on "Ecosystems" a Liability in the Research on Nature's Services? by Baveye, P. C., Chalhoub, M., Choquet, P., and Montagne, D. (2018). Front. Ecol. Evol. 6:226. doi: 10.3389/fevo.2018.00226

\section{OPEN ACCESS}

Edited by:

Luuk Fleskens,

Wageningen University \& Research,

Netherlands

Reviewed by:

Lindsay Stringer,

University of Leeds, United Kingdom

*Correspondence:

Felipe Borrero-Echeverry

fborrero@agrosavia.co

Diego F. Rincon

drincon@agrosavia.co

Specialty section:

This article was submitted to Agroecology and Ecosystem Services,

a section of the journal

Frontiers in Ecology and Evolution

Received: 05 February 2019 Accepted: 04 March 2019 Published: 26 March 2019

Citation:

Borrero-Echeverry F and Rincon DF (2019) Commentary: Is the Focus on "Ecosystems" a Liability in the

Research on Nature's Services?

Front. Ecol. Evol. 7:79.

doi: 10.3389/fevo.2019.00079
Recently, Baveye et al. (2018) published a perspective article in which they argue that the term "ecosystem services" (ES) has inherent flaws in describing the benefits humans derive from nature. The authors argue that a paradigm shift in terminology toward "nature's contributions to people" (NCP) is necessary for three reasons. The first is that the term ES imposes restrictions on the range of services that can be included in the definition, both theoretically and practically due to the very definition of ecosystems. Their second argument is that the term ecosystem makes the accurate measurement of the services provided complicated. Lastly, they argue that stakeholders, mainly land managers, do not relate ecosystems with their day-to-day lives and as such, are less invested in the sustainable management of resources. We argue that these three arguments are counterproductive, not only to the research of nature's services, but also to the ongoing struggle to shift to a more sustainable development.

The authors justify the liability of the concept of ES with the need to integrate natural with "anthropized" or "managed" ecosystems. However, the concept of ecosystem is wide enough to engulf systems with different levels of human intervention. Although the term ES has an obvious anthropocentric connotation [as argued by Silvertown (2015)], the definition of ecosystem has always included humans as active agents that belong to a complex system, just as other living organisms do. In fact, one can argue that reasonable approaches to ecosystem management should consider humans as integral components of a system, mainly because there is no ecosystem on earth that has not been affected by human activities. In contrast, the use of the concept of NCP, as proposed by Baveye et al. (2018), segregates human activity from ecological dynamics and establishes the damaging conception of an ever-providing nature and an ever-receiving humanity. Moreover, simplifying the human-nature relationship to the contribution of one to the other may increase the temporal rate at which stakeholders devalue long-term ecosystem services (Dasgupta and Heal, 1980). In other words, emphasizing on NCP may cause people to weigh the short-term utility over their responsibility for a healthy environment, and their consciousness for the potential consequences of habitat destruction, overpopulation, and climate change.

The second point is moot. Arguing that the inherent methodological difficulties in ecological research may be resolved, or simplified by changing a term makes little sense. It is clear that an ecosystem has more variables than can ever be measured and, moreover, that in most cases are site specific. As scientists, we can only do our best to approach this difficulty by properly planning hypothesis driven research to make plausible abstractions of such a complex matrix of interactions. 
Lastly, Baveye et al. suggest that a change in terminology will facilitate communicating with various stakeholders since their parcels of land rarely encompass an entire ecosystem and as such, they do not relate to the term ecosystem. In reality, this is only partially true. While it is true that most land managers do not own large extensions of land, this doesn't mean that they do not own ecosystems. Designation of particular ecosystems is quite arbitrary. Even small plots have community dynamics and abiotic interactions that provide ecosystem services to farmers, and large areas of land are hardly considered isolated ecosystems. Productive land, regardless of its size, is embedded in, and interacts with, the area or ecosystems around it (Kremen and Ostfeld, 2005). Thus, we find it both counterproductive and irresponsible to remove the term ecosystem from the discussion with stakeholders under the assumption that ecosystems have a minimum effective area.

We agree on the importance of including stakeholders in this discussion. However, rather than narrowing the discussion to their own plots and immediate interests (what nature can provide to them), we should be working together toward understanding the larger picture (how we may coexist with our environment). We need stakeholders to understand that their surroundings affect them just as much, if not more so, than the internal factors of their land. That by thinking about themselves as part of a wider system, and integrating into it, rather than separating themselves from it, not only do they benefit, but the community and region benefit as well (Prager et al., 2012). It is impossible to speak about, and work toward, the sustainability of systems if we break them down to their simplest components. Stakeholders are capable of understanding both the immediate and long-term advantages of ES if they are included in the discourse. What's important is that there be constant interaction between scientists, land managers, and the private and public sectors (Dick et al., 2017).

It is surprising that there is not even a single mention of the word "sustainability" in a manuscript devoted to making an argument about ES (except for the keywords). Yet, the

\section{REFERENCES}

Baveye, P.C., Chalhoub, M., Choquet, P., and Montagne, D. (2018). Is the focus on "ecosystems" a liability in the research on nature's services? Front. Ecol. Evol. 6:226. doi: $10.3389 /$ fevo.2018.00226

Dasgupta, P. S., and Heal, G. M. (1980). Economic Theory and Exhaustible Resources. Cambridge: Cambridge University Press.

Dick, J., Turkelboom, F., Woods, H., Iniesta-Arandia, I., Primmer, E., Saarela, S,-R., et al. (2017). Stakeholders' perspectives on the operationalisation of the ecosystem service concept: results from 27 case studies. Ecosyst. Serv. 29, 552-565. doi: 10.1016/j.ecoser.2017.09.015

Folke, C., Hahn, T., Olsson, P., and Norberg, J. (2005). Adaptive governance of social-ecological systems. Annu. Rev. Environ. Resour. 30, 441-473. doi: 10.1146/annurev.energy.30.050504.144511

Hastings, A., and Gross, L. J. (eds.). (2012). Encyclopedia of Theoretical Ecology. Berkley; Los Angeles, CA: University of California Press.

Holling, C. S., and Gunderson, L. H. (2002). Panarchy: Understanding Transformations in Human and Natural Systems. Washington, DC; Covelo, CA; London: Island press.

Kremen, C., and Ostfeld, R. S. (2005). A call to ecologists: measuring, analyzing, and managing ecosystem services. Front. Ecol. Environ. 3, 540-548. doi: 10. 1890/1540-9295(2005)003[0540:ACTEMA]2.0.CO;2 concept of sustainability is not trivial when discussing ecosystem services, since the whole idea behind valuing the benefits and contributions of ES to human livelihood is the promotion of sustainable development. Modern definitions of sustainability are fed by several disciplines, because they are strongly linked to the theory on complex systems (interdisciplinary by definition) and their resilience to the ever-changing conditions of the context (e.g., Holling and Gunderson, 2002; Hastings and Gross, 2012). Resilience is an intrinsic property of such systems, and should be considered when designing research, policies and practices associated with the relationship between human interests and natural areas. Replacing the concept of ecosystem with NCP (thus removing the term "system") would discourage interdisciplinary research on sustainability, because systems thinking, and its diverse set of approaches, would be oversimplified to what we, as humans, can extract from nature. Moreover, fundamental properties of complex systems, along with many significant theoretical achievements in sustainable management that were conceived from several social, economic and ecological fields (e.g., Holling and Gunderson, 2002; Folke et al., 2005; Plumecocq et al., 2018), will lose relevance for scholars, managers and practitioners if they are seen merely in light of what nature can contribute to people. Altogether, getting away from the systems thinking and emphasizing the linear contribution of nature to humans may erode people's self-identity as part of a shared and complex world.

\section{AUTHOR CONTRIBUTIONS}

All authors listed have made a substantial, direct and intellectual contribution to the work, and approved it for publication.

\section{FUNDING}

Salary and research support for FB-E and DR are provided by Colombian public funds assigned to AGROSAVIA.

Plumecocq, G., Debril, T., Duru, M., Magrini, M.-B., Sarthou, J. P., and Therond, O. (2018). The plurality of values in sustainable agriculture models: diverse lock-in and coevolution patterns. Ecol. Soc. 23:21. doi: 10.5751/ES-09881230121

Prager, K., Reed, M., and Scott, A. (2012). Encouraging collaboration for the provision of ecosystem services at a landscape scaleRethinking agri-environmental payments. Land Use Policy 29, 244-249. doi: 10.1016/j.landusepol.2011.06.012

Silvertown, J. (2015). Have ecosystem services been oversold? Trends Ecol. Evol. 30, 641-648. doi: 10.1016/j.tree.2015.08.007

Conflict of Interest Statement: The authors declare that the research was conducted in the absence of any commercial or financial relationships that could be construed as a potential conflict of interest.

Copyright (๑) 2019 Borrero-Echeverry and Rincon. This is an open-access article distributed under the terms of the Creative Commons Attribution License (CC BY). The use, distribution or reproduction in other forums is permitted, provided the original author(s) and the copyright owner(s) are credited and that the original publication in this journal is cited, in accordance with accepted academic practice. No use, distribution or reproduction is permitted which does not comply with these terms. 